\title{
Sponges as a complement of sedimentary facies analysis in island deposits of Upper Paraná River
}

\author{
I.P. Zviejkovski ${ }^{\text {a, }}{ }^{*}$, J.C. Stevaux ${ }^{\text {a, b }}{ }^{\text {, I.T. Leli }}{ }^{c}$, M. Parolin ${ }^{\text {d }}$, J.B. Campos ${ }^{\text {a }}$ \\ a Universidade Estadual de Maringá/ Pós-graduação Em Ecologia de Ambientes Aquáticos Continentais, UEM, Av. Colombo, 5790, 87020-900, Maringá, PR, \\ Brazil \\ ${ }^{\mathrm{b}}$ Universidade Estadual Paulista/Pós-graduação Em Geociências e Meio Ambiente, UNESP, Av. 24 A, 1515, 13506-900, Rio Claro, SP, Brazil \\ c Universidade Do Oeste Do Paraná/Pós-graduação Em Geografia, UNIOESTE, R. Pernambuco, 1777, 85960-000, Marechal Cândido Rondon, PR, Brazil \\ d Universidade Estadual Do Paraná/Laboratório de Estudos Paleoambientais da Fecilcam/Lepafe, Av. Comendador Norberto Marcondes, 733, 87302-060, \\ Campo Mourão, PR, Brazil
}

\section{A R T I C L E I N F O}

\section{Article history:}

Received 31 March 2017

Received in revised form

25 July 2017

Accepted 26 July 2017

Available online 1 August 2017

\section{Keywords:}

Freshwater sponges

Forest succession

Hydrach stages

River paleoecology

Sedimentary facies

Paraná river

\begin{abstract}
A B S T R A C T
This paper shows the importance of the sponge spicules as complement of sedimentary facies analysis in order to reconstruct the hydrach stages involved in island formation in the Upper Paraná River, Brazil. River in the study reach is anabranching with islands of different sizes covered by typical alluvial forest. We noted that the sponge spicules communities vary according to the changes in the environments involved in the island formation processes. The sponges were identified by their microscleres and gemoscleres in optical microscope as Metania spinata, Oncosclera navicella, Oncosclera jewelli, and possibly the genus Corvoheteromeyenia sp. (Ezcurra de Drago, 1979). By correlating the information coming from the sponges and sedimentary facies, it was possible to identify five phases of the island construction and their respective hydrach stages: 1) bar-island channel (Eupotamic stage), 2) blind channel (Parapotamic stage), 3) lake, 4) swamp (both Paleopotamic stage), and 5) forested island (Terrestrial stage). Using ${ }^{14} \mathrm{C}$ dating and rate of sedimentation, we observed that the development of these five phases took $\sim 900-1000$ years. The data also supported the idea that the forest begin to be formed 134-160 years ago. We concluded that sponge is a strong tool on paleoenvironmetal reconstruction when used with another indicators (in this case the facies analysis) and can be applied other fluvial studies as river management especially for long-term impacted systems (by dams) as those of the Paraná River Basin.
\end{abstract}

() 2017 Elsevier Ltd. All rights reserved.

\section{Introduction}

The variety of vegetation in alluvial rivers is a dependent variable of water and sediment flow regimes (Ward and Stanford, 1995). The regime dynamics also have an important role in ecological succession (Chiarello et al., 1998). Thus, natural or manmade disturbances in the physical variables of the river (flow regime, flood tension, sediment yield, flow velocity, etc.) can change the rate and pattern of ecological succession (Odum, 1988).

Disturbances are key drivers of forest ecosystem dynamics, and forests are well adapted to their natural disturbance regimes (Seidl et al., 2014). According to Casco (2003), the distribution and abundance of vegetation in islands and floodplains are controlled

\footnotetext{
* Corresponding author.

E-mail address: iupz@hotmail.com (I.P. Zviejkovski).
}

by periods of floods and drought and by the resilience of the vegetation. Stevaux et al. (2013), who studied the Upper Paraná River, claimed that morphological characteristics, particularly the topography of islands and floodplains, have different degrees of connectivity (frequency, permanence, recurrence and tension) with the channel water flow, which controls the riparian vegetation distribution. Moreover, those authors affirmed that vegetation development is controlled by the evolutionary stage of the island and floodplain morphologies. The process of lateral or frontal attachment of sand bars forms large parts of the islands of the Upper Paraná River (Santos et al., 1992; Fernandez and Souza Filho, 1995; Leli et al., 2017). A succession of sub environments is triggered during the process of attaching bars on the banks and islands. Leli et al. (2017) identified the hydrach stages of subenviroments involved in the incorporation of a bar to the island according to a gradual reduction of the degree of connectivity (Fig. 1). (I) The 
eupotamic stage describes when a lateral bar is deposited beside a preexistent island, forming a bar-island channel between them. During this stage, the water in the canal has free circulation between the island and the bar deposited laterally; it is an environment of total connectivity (Eupotamic) with the water of the canal. (II) The succession of sub environments is followed by the parapotamic stage, when the island-bar channel is closed upstream, forming a blind channel (Leli et al., 2017). In this environment, the connectivity with the channel water is made only through a downstream mouth. (III) The paleopotamic stage describes when the blind channel becomes a lake with the closure of its downstream mouth. The connectivity with the channel water is extremely reduced and is made only during floods. The aforementioned authors show that in the parapotamic and paleopotamic stages, the physical and chemical parameters of the water are quite modified compared with channel's water. The isolated water body continues under sedimentation during the floods, transforming itself in a swamp and allowing the settlement of root
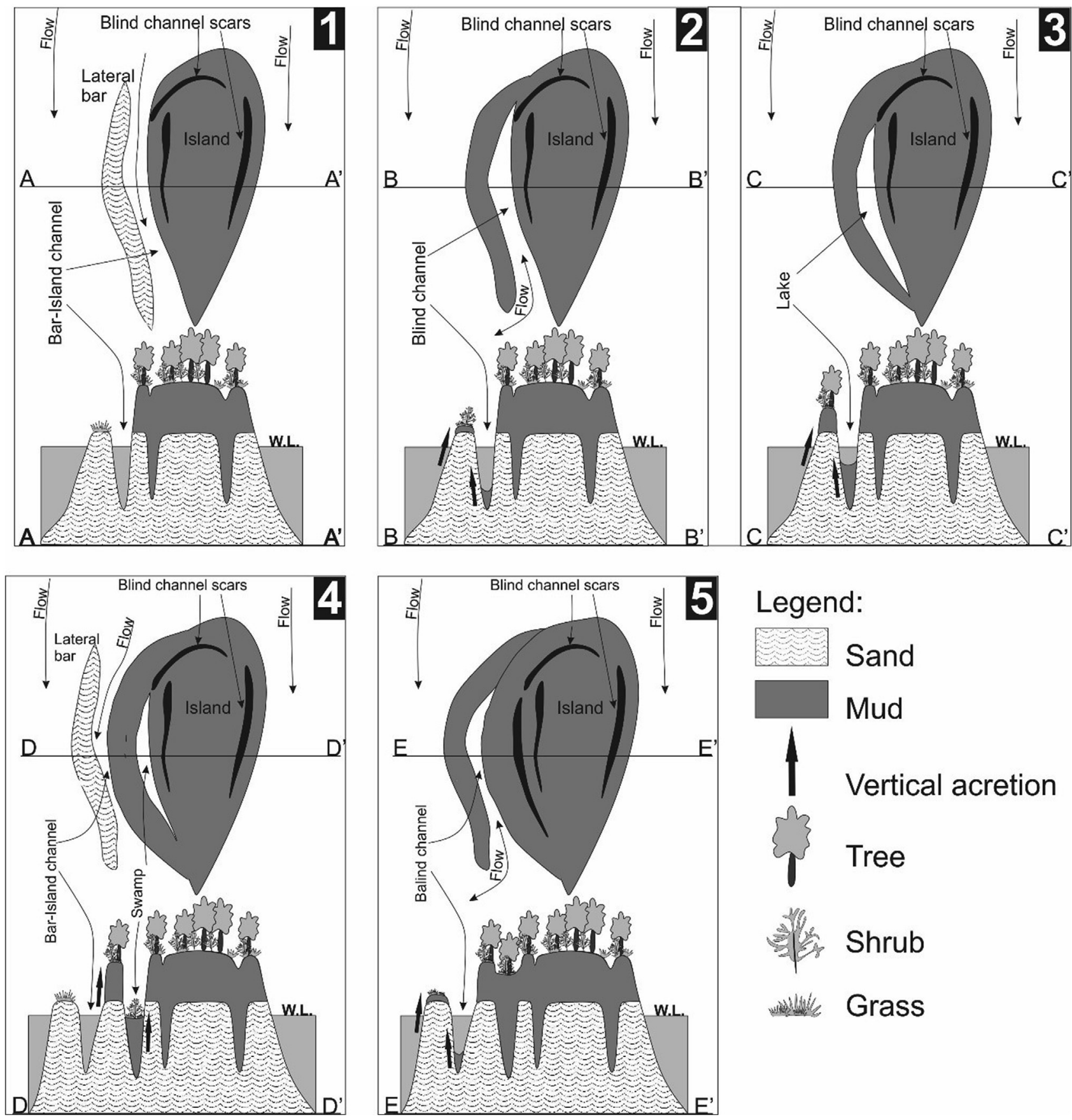

Legend:
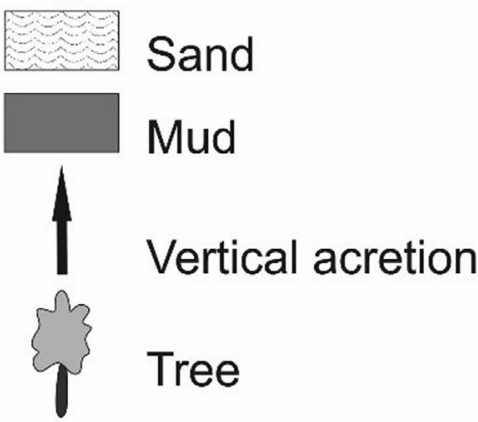

Tree

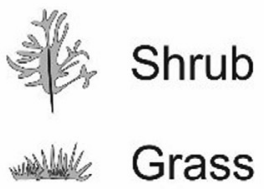

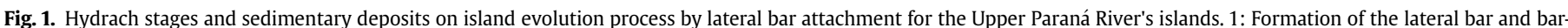

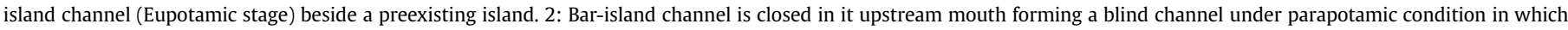

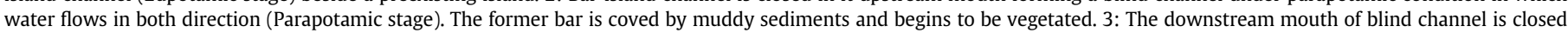

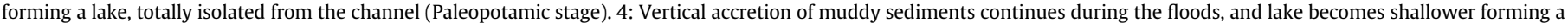

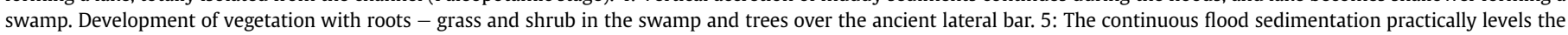
island's sub environments that acquire terrestrial conditions. At this condition the riparian forest covers entire island. 
vegetation. (IV) The terrestrial stage describes when the continuous vertical aggradation elevates the environmental surface up to the level of the preexistent islands and natural levees; therefore, the connectivity occurs only at bankfull discharges. This sub environmental evolution is also recorded in the sedimentary deposits and can be reconstructed by facies analysis (Leli et al., 2017) (Fig. 1).

Island evolution is followed by modifications of the vegetation characteristics, from pioneer grass vegetation, when still in the bar phase, up to island forest, when the terrestrial condition is reached in a process that can extend for $10^{1}-10^{3}$ years, (Stevaux et al., 2009). Thus, for complete comprehension of an island forest formation, it is necessary to understand the morphological evolution and the environmental succession involved in island construction. The studies of island reconstructions and forest settlement involve not only sedimentary facies analysis (sediment texture and sedimentary structures) and event chronology $\left({ }^{14} \mathrm{C}\right.$, OSL, ${ }^{210} \mathrm{~Pb}$ dating, and historical aerial photographs or satellite images) but also a group of biological indicators in the sediment. A more precise information concerning, for instance, water quality, climate, vegetation landscape and paleoecology are possible only with the use of biological indicators (e.g. Frenzel and Boomer, 2005). Although not frequent in fluvial studies, biological indicators have been used in the last decade in the Upper Paraná, Ivaí, Madeira and Pantanal rivers and have included pollen (Feitosa et al., 2015), sponges (Gonçalves, 2014), seeds (Ramírez, 2014), diatom frustules (Brassac et al., 1999) and, more recently, phytoliths (Rasbold, 2016).

Among the biological indicators, sponge spicules have been shown to be a powerful tool for paleoenvironmental and paleoecological reconstructions (Batista et al., 2003, 2007; Parolin et al., 2003, 2007; Volkmer-Ribeiro et al., 2007; Parolin et al., 2008; Almeida et al., 2009; Kuerten et al., 2013). In addition, the use of sponges as a bio-indicator is, relatively easy and usually less expensive in both collecting and processing procedures compared with other bio-indicators, such as pollen, phytoliths and diatoms. Because of their siliceous composition, although there are carbonate spicules, they are resistant to weathering and especially to oxidation processes, very common in tropical environments, unlike seeds and pollens (Parolin et al., 2008).

This paper utilizes, for the first time, sponge spicules and chronologies in order to enhance the results obtained by the previous facies analysis studies (Leli, 2015), by giving a more detailed environmental characterization. Paleoenvirnmental analysis of fluvial systems usually uses traditional sedimentary facies tools, and provides information about paleoflow and geomorphological information restrict to two major fluvial sub environments: channel and floodplain (see the classical literature as Miall, 1978, 1985, and Smith, 1983, 1986). On the other hand, the more generalize used of pollens in fluvial sediments gives a general paleoclimatological information. Sponges, by its sedentary habit can inform some detailed characteristics of environments as water quality, water body depth, flow characteristics (lentic or lotic). Base in these facts we hope to improve paleoenvironmental studies with a strong tool, especially on fluvial systems evolution and metamorphosis. We believe that the use of sponges in sediments will also permit, in the future, to help in the assessment of long-term human impacted fluvial systems, especially in the tropics, as well, refine the quality of information on climate changes.

In addition, this work also presents a brief consideration of island forest formation and island development.

\section{Materials and methods}

\subsection{Site description}

Porto Rico Island is located in the Upper Paraná River $\left(22^{\circ} 45^{\prime} \mathrm{S} /\right.$ $53^{\circ} 15^{\prime} \mathrm{W}$ ) at $230 \mathrm{~m}$ a.s.l (Fig. 2). and belongs to the "Islands and Floodplain Environmental Protection Area of the Upper Paraná River", a conservation unit created in 1997 by the federal government for environmental protection of the area. The river channel has an anabranching pattern, formed by elongate islands varying from hundreds to thousands of meters long and emergent sand bars at medium water levels. In the study area, the channel has a slope of $0.00005\left(5 \mathrm{~cm} \mathrm{~km}^{-1}\right)$ and an average discharge of $9000 \mathrm{~m}^{3} \mathrm{~s}^{-1}$, with historical records of $Q_{\max }=33,000 \mathrm{~m}^{3} \mathrm{~s}^{-1}$ and $Q_{\min }=4500 \mathrm{~m}^{3} \mathrm{~s}^{-1}$ (Stevaux, 1994). The climate is tropical-subtropical, classified by Köppen as Cfa, with a hot summer (annual average is $22^{\circ} \mathrm{C}$ ) and an annual rainfall of $1500 \mathrm{~mm}$ (Campos and Costa-Filho, 1994). The regional vegetation belongs to the Semideciduous Seasonal Forest Phytoecological Region (IBGE, 2012) and is classified as a semidecidual seasonal alluvial forest (Campos and Souza, 1997).

The islands and floodplains present a complex vegetation mosaic in which tall trees occur in the highest areas such as natural levees and paleo-islands, while shrubs and herbaceous grasses are found in low and frequently flooded areas. The lowest areas are characterized by swamps, lagoons and floodplain channels and are colonized by aquatic macrophytes (Casco, 2003; Casco et al., 2005; Corradini et al., 2008; Samizava et al., 2011; Stevaux et al., 2013).

Porto Rico Island has a slight rhombohedral morphology that is $2.5 \mathrm{~km}$ long and $0.6 \mathrm{~km}$ wide. A large blind channel that is $2 \mathrm{~km}$ length by $30 \mathrm{~m}$ wide occurs on the right side of the island. The former blind channels shape the island topography with a sequence of parallel scars, with crests and troughs up to $1.5 \mathrm{~m}$ in depth and $2.0 \mathrm{~m}$ in height (Leli et al., 2017). The area was intensively deforested for pasture during the years of 1970 and 1980, with only 6.17 ha $(8 \%)$ out of an original area of 93.3 ha of forest remaining (Campos, 1999) where the study core was drilled. At this site, Zviejkovski (2008) made a phytossociological survey in a forest remnant of the original vegetation that covered the island. According to the author, the inventoried forest has structural and qualitative attributes similar to those found in primary forests.

\subsection{Sampling}

Samples were obtained from a $270 \mathrm{~cm}$ long core, procured via vibro-corer drilling in Porto Rico Island $\left(22^{\circ} 45^{\prime} 26.90^{\prime \prime} \mathrm{S}\right.$, $\left.53^{\circ} 15^{\prime} 56.73^{\prime \prime} \mathrm{W}\right)$. Textural, facies and sponge analyses were performed in the LEPAFE/Faculdade Estadual de Ciências e Letras de Campo Mourão, Brazil. The sample to dating was collected about $1 \mathrm{~cm}$ thick, at $260 \mathrm{~cm}$ depth, to accelerator mass spectrometry (AMS) and ${ }^{14} \mathrm{C}$ dates that was processed at the University of Georgia in the USA. The samples were obtained at $5 \mathrm{~cm}$ intervals along the core and were catalogued in the LEPAFE Collection under the numbers L.187; 188.C.17. For spicules extraction, the sediment was dried at $50^{\circ}$ until reaches constant weight. From each sample, a $1 \mathrm{~g}$ aliquot was separated and submitted to chemical treatment according to the method of Volkmer-Ribeiro and Turcq (1996): a) heating the aliquot in $\mathrm{HNO}_{3}$, (60\%); b) after natural cooling, the material was washed by centrifugation $(1.000 \mathrm{rpm})$ several times with distilled water until pH stabilization (7); c) alcohol (60\%) was used in the last centrifugation and last alcohol washing. For slide elaboration, $50 \mu \mathrm{m}$ of material was dropped over a slide, dried up in hotplate at $60{ }^{\circ} \mathrm{C}$, covered by Entellan ${ }^{\circledR}$ and cover slips. Spicules were quantified under optical microscope (640x), with five transects by slide in three slides by aliquot. Spicules diagram was made using Tilia Graph $^{\circledR}$ e Corel draw ${ }^{\circledR}$ software.

The identification of spicules was based on the LEPAFE's reference collection and literature (Volkmer-Ribeiro and Pauls, 2000; Parolin, 2006; Parolin et al., 2008; Volkmer-Ribeiro and Parolin, 2010). We have identified and quantified the whole megascleres (robust and fragile) and megascleres fragments. 


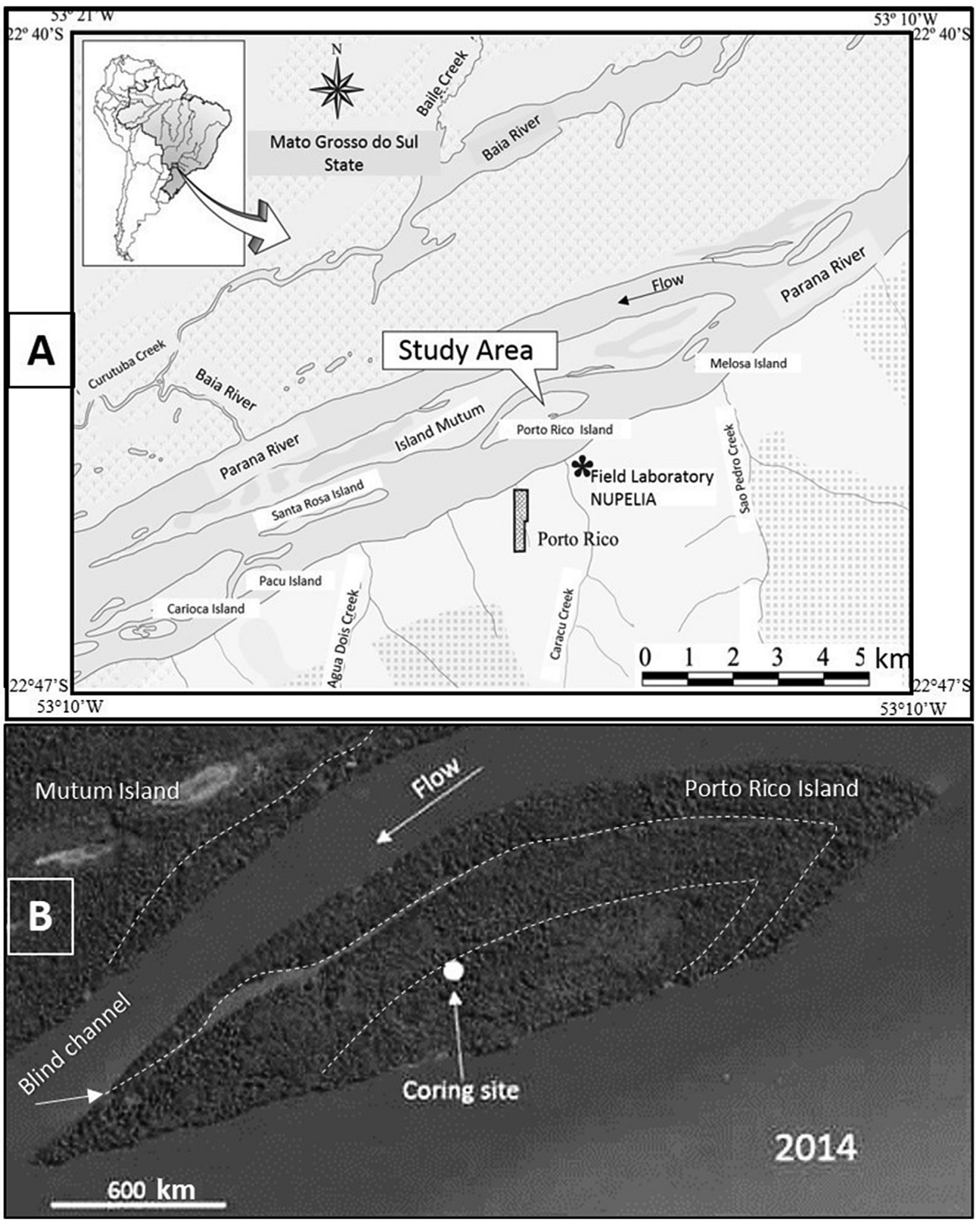

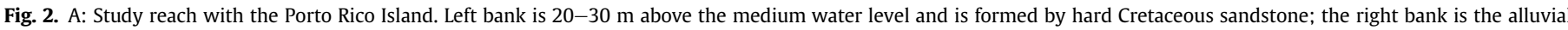

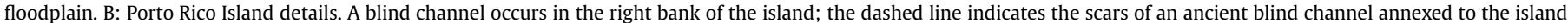

\section{Results}

\subsection{Sponge spicule identification}

Were identified the following sponges: Metania spinata (Carter, 1881), Oncosclera navicella (Carter, 1881), Oncosclera jewelli
(Volkmer, 1963) and probably the genus Corvoheteromeyenia sp (Ezcurra de Drago, 1979). (Fig. 3).

\subsection{Sedimentary facies analysis}

Leli et al. (2017) concluded that the islands of the Upper Paraná 
River develop by a complex process involving the formation since the formation of a lateral bar to its entire incorporation to the island. Sedimentary records of this process show a typical group of facies (Table 1). The sedimentary deposits from Porto Rico Island present two major lithosomes: a basal sandy interval and a muddy sequence in the top (Fig. 4). Six sedimentary facies were recognized (Table 1) and related to their depositional environments.

\subsection{Data analysis and interpretation}

Sponge data were plotted by their abundance (Fig. 4) along with their sedimentary environments, which were derived according to the facies analysis. Thus, from the integrated analysis of the bioindicators and facies deposits, it was possible to identify five process-environment phases in the construction of Porto Rico Island.

\subsubsection{Phase I (bar-island channel: $270-210 \mathrm{~cm}$ )}

It is the first phase of the entire sedimentary process that happens to form the blind channel, and therefore, the oldest sediment, 920 years (Fig. 4). The deposition is formed by lateral sand bar. Santos et al. (2017) affirms that these bars are normally deposited 10-15 m away from islands, forming a channel between island and bar (bar-island channel) (Figs. 1 and 5). Leli et al. (2017) have studied the formation, sedimentation and evolution of these environments and have concluded that the island-bar channel develops bed forms (mega-ripples) and has a sediment texture (fine to medium sand) similar to that of the channel, corresponding with the crossstratified sand facies found at the sedimentary profile base (Fig. 4). In this phase, no bioindicators were found because the high velocity of the water flow hinders its sedimentation.

\subsubsection{Phase II (blind channel: $210-147 \mathrm{~cm}$ )}

The upstream mouth of the bar-island channel generally closes because of intensive sedimentation of sand bars and logs (Leli et al., 2017), forming a blind channel (Figs. 1 and 2B). This phase consists of a predominance of whole and robust megascleres like betamegasclere of Metania spinata (at $165 \mathrm{~cm}$ in depth), Oncosclera navicella gemoscleres and Corvoheteromeyenia sp. microscleres spread throughout the whole interval. The low density of sponge spicules fragments suggests a semi-lotic environment (Fig. 4). Ephemeral lotic conditions could occur with sufficient energy to promote events of bed erosion. Leli et al. (2017) have shown that the presence of massive sand to rippled sand facies indicates twoflow conditions, in which the semi-lotic flow is predominant and the lotic condition is formed only during floods. Organic material and vegetal fragments are also indicative of a low flow velocity and indicate a typical blind channel environment.

\subsubsection{Phase III (lake: $147-80 \mathrm{~cm}$ )}

With time, the downstream mouth of the blind channel is also closed, producing a lake isolated from the channel under paleopothamon conditions (Fig. 6a, b). In the deposits of this lake, the high abundance of whole and fragmented sponge spicules suggests a depositional environment resulting in periodic and regular floods (Fig. 4). In this phase, the environment was lentic for the majority of the time, with ephemeral lotic conditions produced by flooding events, creating an oscillation in spicules megascleres densities. The presence of Corvoheteromeyenia sp. and gemoscleres of Oncosclera navicella megascleres is observed for the entire interval of this phase. $O$. navicella spicules have been related to lotic environments subject to floods (McGlue et al., 2012; Kuerten et al., 2013). The interval result in discreetly laminated mud at the base, passing to predominantly mottled mud, formed by intensive root bioturbation. This is suggestive of a progressive shallowing of the body of water with the development of rooted plants, organic material and vegetal fragment accumulation.

\subsubsection{Phase IV (swamp: $80-25 \mathrm{~cm}$ )}

This is a continuation of the shoaling of the lake by flood sedimentation, generating a swamp environment (Fig. 6c). In sediment

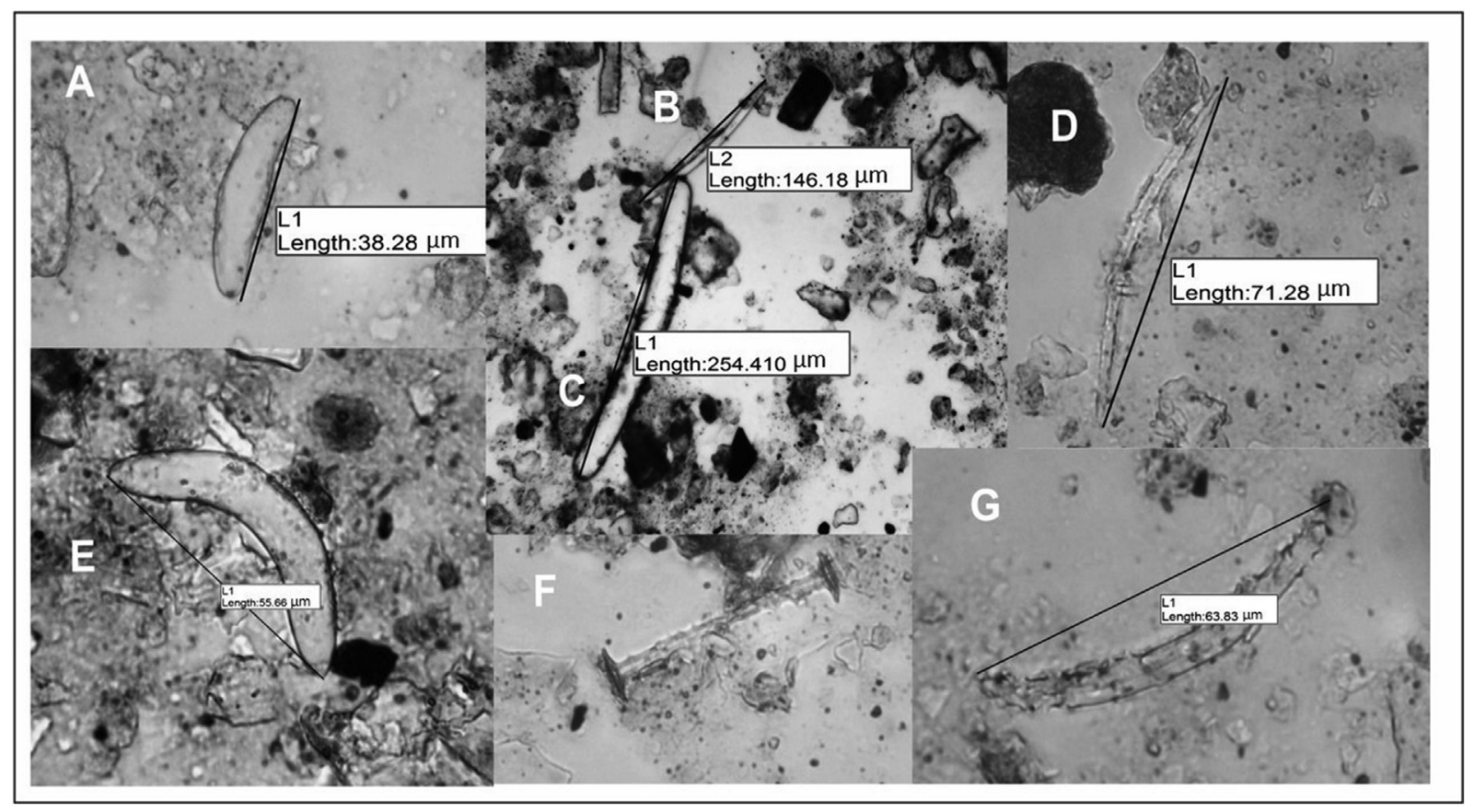

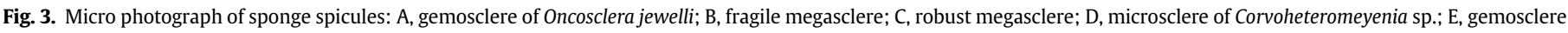
of Oncosclera navicella; F, gemosclere of Corvoheteromeyenia sp.; G, beta-megasclere of Metania spinata. 
Table 1

Facies descriptions and environment characteristics obtained from the island core analysis and hydrach stages (Facies data from Leli et al., 2017).

\begin{tabular}{|c|c|c|c|c|}
\hline Facies (Code) & Description & $\begin{array}{l}\text { Interpreted sub } \\
\text { environment }\end{array}$ & Sponge spicule predominance & $\begin{array}{l}\text { Hydrach stage } \\
\text { (flow characteristic) }\end{array}$ \\
\hline Cross-stratified sand (Sp) & $\begin{array}{l}\text { Fine to medium white, quartz } \\
\text { sand, with planar cross- } \\
\text { stratification }\end{array}$ & $\begin{array}{l}\text { Inter-bar channel } \\
\text { (chute-channel) }\end{array}$ & Sterile & Eupothamic (lothic) \\
\hline Massive/rippled sand (Sm, Sr) & $\begin{array}{l}\text { Fine to very fine massive or } \\
\text { rippled sand with organic } \\
\text { material }\end{array}$ & Closed-channel & Megasclere (whole and fragments) & Parapothamic (semi-lothic) \\
\hline $\begin{array}{l}\text { Massive and laminated } \\
\text { mud (Fm, Fl) }\end{array}$ & $\begin{array}{l}\text { Medium gray mud massive and } \\
\text { discreetly laminated with } \\
\text { organic material and vegetal } \\
\text { fragments }\end{array}$ & Lake & Megasclere (whole and fragments) & Paleopothamic (lentic) \\
\hline Mottled mud (Fm) & $\begin{array}{l}\text { Light gray mud, massive by } \\
\text { bioturbation mud, with organic } \\
\text { material and vegetal fragments }\end{array}$ & Swamp & Megasclere (whole and fragments) & Paleopothamic (lentic) \\
\hline Reddish massive mud (Fm, Fp) & $\begin{array}{l}\text { Red massive mud with live } \\
\text { leaves and roots }\end{array}$ & $\begin{array}{l}\text { Soil, water only in } \\
\text { bankfull discharges }\end{array}$ & Megasclere (whole and fragments) & Terrestrial with subtle pedogenesis \\
\hline
\end{tabular}

a According to Stevaux et al. (2013) based on Ward and Stanford's (1995) classification.

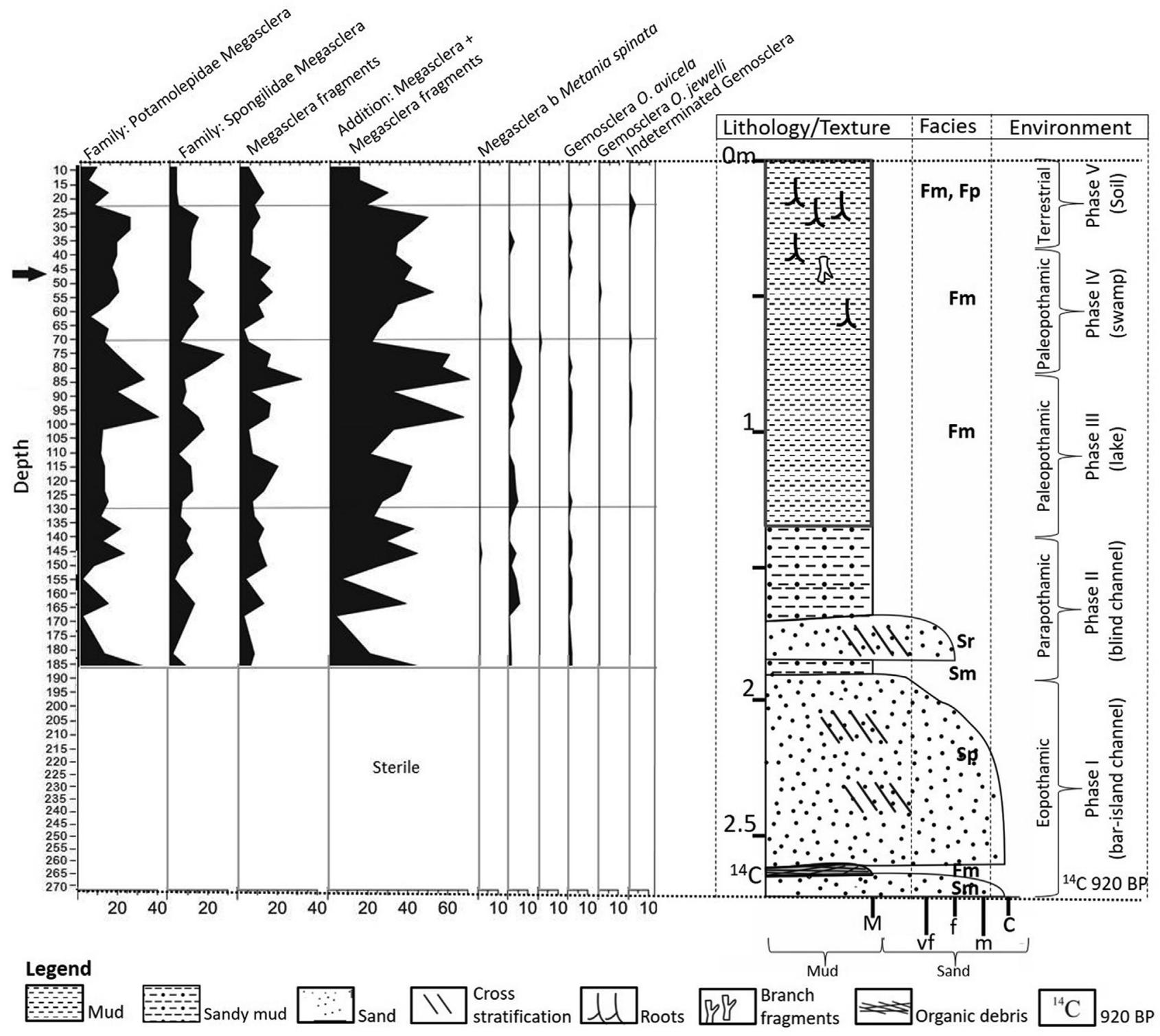

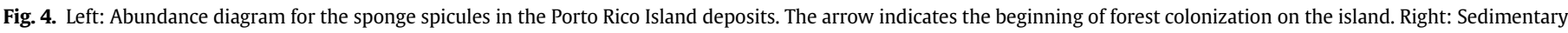
profile of the Porto Rico Island core, facies code and environmental interpretation. 


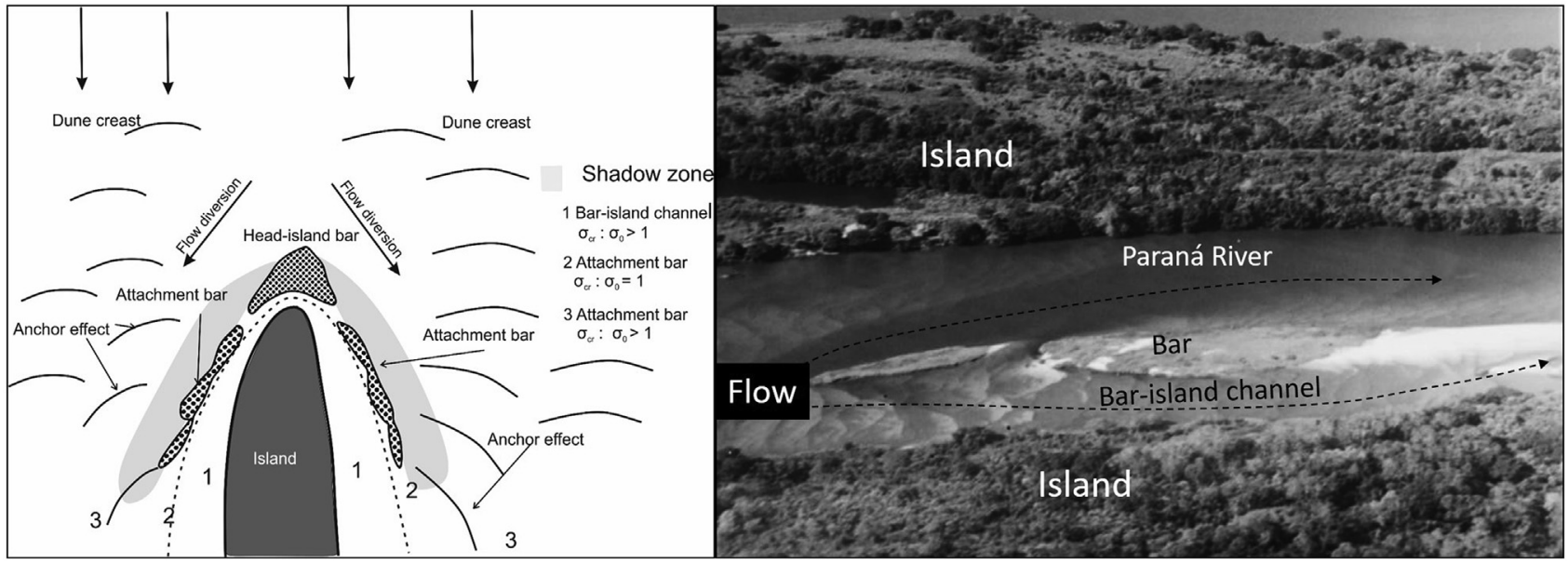

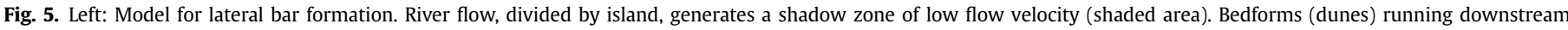

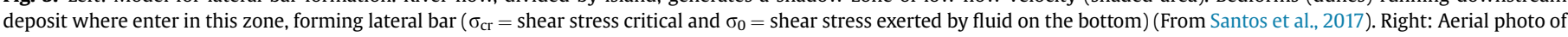
a lateral bar and bar-island channel.
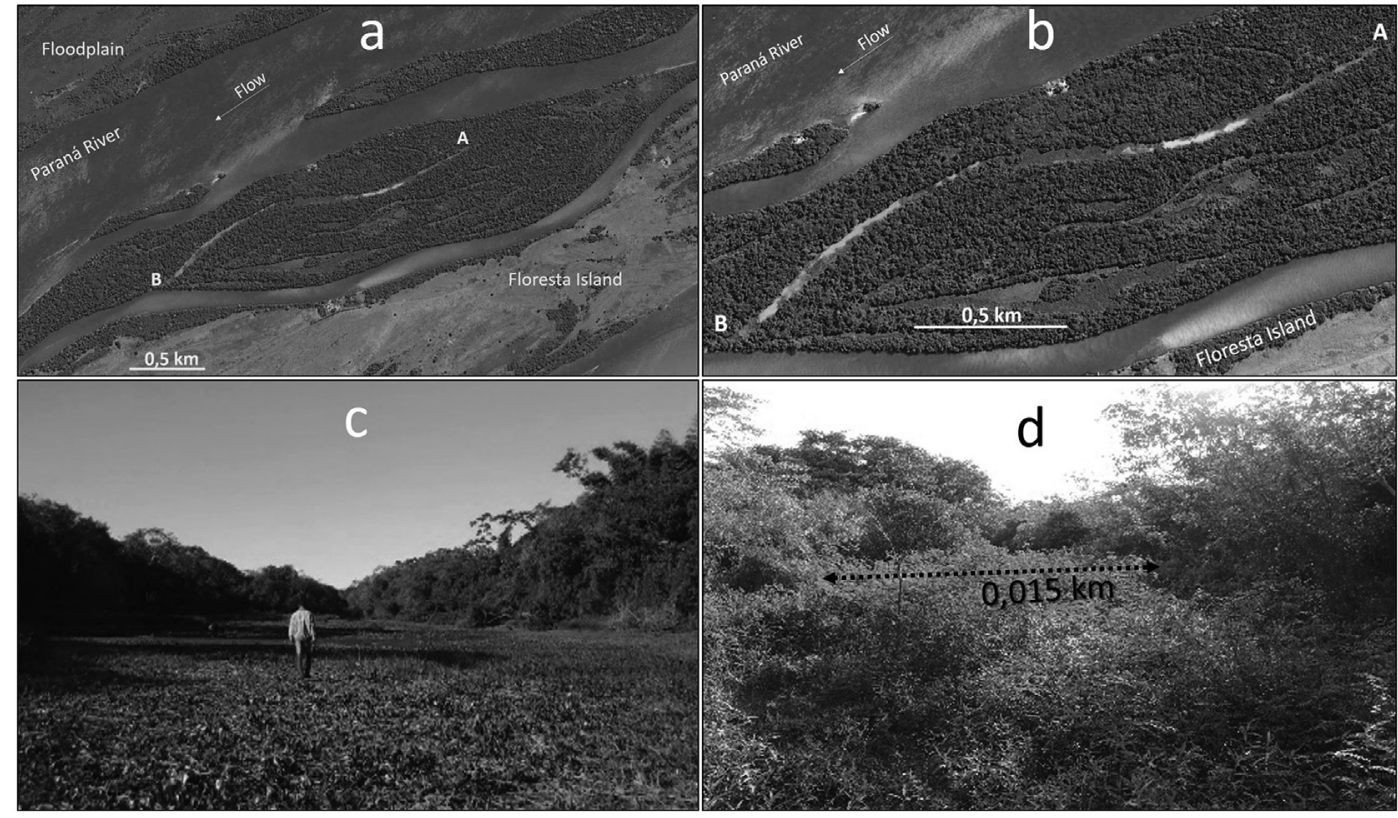

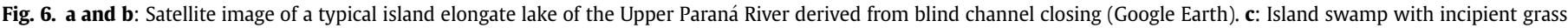
vegetation. d: Young forest over a former swamp between developed island forest. Arrow indicates the width of the ancient bar-island channel.

analysis, the lower densities of the sponge spicules associated with the mottled mud facies suggest an environment with lower connectivity with the main channel compared to phases II and III. The same condition is found in modern island swamps that are depositional environments connected with the channel only during large floods. The presence of $M$. spinata beta-megasclere $(65 \mathrm{~cm}$ in depth) and gemosclere of $O$. navicella and 0 . jewelli $(60 \mathrm{~cm}$ in depth), strengthens this interpretation (Fig. 4).

\subsubsection{Phase V (island: $25-0.0 \mathrm{~cm}$ )}

At this phase, the sedimentary site does not have any connection with the channel water except during large floods. The low densities of sponge spicules is in agreement with this infrequent connectivity. The terrestrial conditions are characterized by reddish mud facies with living roots, which characterize the initial pedogenesis (alluvial soil) that permit tree development and forest formation (Figs. 4 and 6).

\section{Discussion: from channel deposit (eupotamic phase) to forest formation (terrestrial phase)}

Based on the integration of sedimentary facies and the studied biological indicators, it is possible to suggest an "eco-sedimentary" evolution for Porto Rico Island. Cross-stratified sandy deposits were formed in bar-island channel environments under totally eupotamic conditions. It is very difficult to separate island-bar channel from open channel deposits once their flow and sedimentary conditions are similar. This environment does not allow the deposition and occurrence of sponge spicules. Stevaux (1994) and Santos (2005) described the presence of thin layers of leaves in island-bar channel sediments, deposited during low water levels when the flow in the island-bar channel was slower than that in the 
main channel. In the study core, a $5 \mathrm{~mm}$ thick layer of leaf fragments was found and ${ }^{14} \mathrm{C}$ dated to $920 \mathrm{BP}$ Cal (from CALIB Manual 7.1), suggesting that the construction processes of this portion of Porto Rico Island initiated around this time.

At $210 \mathrm{~cm}$ in depth, the presence of fine rippled muddy sand, whole sponge spicules indicate a reduction in the unidirectional flow conditions, probably by blind channel formation in environments with lower channel connectivity (Parapotamic condition). The occurrence of Oncosclera navicella spicules in the blind channel deposits emphasizes the influence of flood flows and not in situ development, as this species lives in the lotic environment of rocky channels (Volkmer-Ribeiro and Pauls, 2000; Batista and VolkmerRibeiro, 2002; Batista et al., 2007) surrounded by riparian vegetation (Santos and Parolin, 2011). Occasionally, O. navicella can occupy vegetal substratum in the floodplains (Volkmer-Ribeiro and Tavares, 1997).

In the lake formed by the blind channel closing (phase III), the presence of Oncosclera jewelli constitutes the first record of the species in the Paraná River. This is an endemic species that is on the list of Brazilian endangered species (Brasil, 2004). In Paraná State, $O$. jewelli has been found only in the Dos Patos River, in the upper Ivaí River Basin (Volkmer-Ribeiro and Parolin, 2010). According to authors, 0 . jewelli is a species associated with the subtropical ombrophilous forest phytophysiognomic domain. However, with the contemporary record still in phase III, this sponge can also be associated with the tropical semidecidual forest domain.

After intensive depositions of muds from the floods (phase IV), the environment became in shallow swampy, with favorable conditions for the development of vegetation adapted to saturated soils. This phase marks the beginning of shrub/tree colonization. This primary vegetation has an important role in the retention of nutrients and sediments from the river (Casco et al., 2005). The presence of Metania spinata beta megasclere at $65 \mathrm{~cm}$ in depth corroborates the interpretation of a shallow swampy environment (Volkmer-Ribeiro and Pauls, 2000; Parolin et al., 2008).

The island surface is characterized by a vertical aggradation limited by the general height of the old island and the natural levees of the channel (phase V). According to Neiff (1986), frequently flooded areas present few structures and diverse vegetation, which agrees with the work of Campos et al. (2000) that showed that the continuous floods cause selective stress, restricting the environment to a few adapted species. As such, it is possible that the forest was established only at the end of phase IV and during the phase $\mathrm{V}$ (the last $45 \mathrm{~cm}$ at the top of the core). Indeed, living root remains associated with indications of incipient pedogenesis are very frequent in this interval, suggesting colonization by pioneer plants.

Zviejkovski (2008), using the diameter at breast height (DBH) method, estimated that the present aspect of the Porto Rico Island forest began 134 years ago, and remains today. The structural and phytosociological conditions of the modern forest indicate that the area is in an advanced successional process. Riparian forests in climax generally have large trees, dead standing trees, and large fallen trunks, as well as a stratified canopy and diverse understory (Naiman et al., 1998). In addition to the structural characteristics mentioned, the study area presents a high percent of secondary and climax species in both strata (Zviejkovski, 2008). Using a sedimentation rate of $3.0 \mathrm{~mm}$ estimated by Stevaux and Souza (2004) for floodplain muddy deposits in this area, it was possible to obtain an age of 160 years for beginning of forest development. A value very similar to that obtained by attribute to the island forest obtained by Zviejkovski (2008) through the DBH method.

\section{Conclusions}

Through the integrated use of sponge spicules and sedimentary facies analyses, it was possible to identify a more accurate mechanism and age for the evolution of Porto Rico Island and its vegetal colonization. The bioindicators and sedimentation phases correspond with the stages of the evolution of Porto Rico Island.

The evolution of Porto Rico Island can be described through five phases: 1) The eupotamic phase (bar-island channel) - under lotic flow, sand bar sedimentation occurs without bioindicators due to the high energy flow. 2) The parapotamic phase (blind channel) under semi-lotic flow, the sedimentary processes are similar to those in channel abandonment, with ephemeral lotic flow during floods, when water channel enters in the blind channel, and during very low water stages, with inverse fluxo - water runs from blind channel to river channel (Leli et al., 2017). Organic material and vegetal fragments are also indicative of a low flow velocity. This environmental allows for the development of whole megasclere of robust megascleres, beta-megasclere of $M$. spinata megasclera, O. navicella gemoscleres and Corvoheteromeyenia sp. microscleres throughout the whole interval. 3) The paleopotamic phase (lake) under lentic conditions, discreetly laminated and mottled mud is deposited. The environment is sufficiently shallow for the development of rooted plants, fragments of vegetation accumulation, and organic material. The ephemeral lotic conditions caused by flood events produce oscillations promoting spicules megascleres density. The presence of Corvoheteromeyenia sp. and gemoscleres of 0 . navicella megascleres is observed for the entire interval of this phase. 4) The paleopotamic phase (swamp) - under lentic conditions, very shallow water is observed, along with a rapid decrease of sponge spicules density associated with the mottled mud facies, suggesting an environment with lower connectivity with the main channel. The presence of $M$. spinata beta-megasclere and gemosclere of $O$. navicella and $O$. jewelli strengthens this interpretation. 5) Terrestrial phase: The terrestrial conditions with reddish mud facies and living roots characterize the island soil, pointing to the development of trees and forests. The presence of sponge spicules number is very low, which is in agreement with its infrequent connectivity with the main channel.

This study can be a very helpful tool for river resource management in large multichanneled river systems that are intensively dammed, as is the case in the Paraná River. Environments with long relaxation times, such as that of the study island, are products not only of the present processes but also of a centennially to millennial time scale evolution. On the other hand, changes in sediment and water flow regime, such as those introduced by dams, can affect fluvial island environments on the same time scale. The results from this study can be used to inform mitigation measures taken to reduce the impacts of altered flow regimes and sediment yields caused by the dams on the Parana River on island environments.

\section{References}

Almeida, A.C.S., Volkmer-Ribeiro, C., Varajão, A.F.D.C., Gomes, N.S., Varajão, C.A.C., 2009. Espículas de Esponjas Continentais nos Sedimentos Cenozóicos do Noroeste de Minas Gerais, como Indicadores Paleoambientais. Rev. Bras. Paleontol. $12,123-138$.

Batista, T.C.A., Volkmer-Ribeiro, C., 2002. Comunidades de esponjas do curso superior dos rios Paraná (Goiás) e Paraguai (Mato Grosso), Brasil, com redescrição de Oncosclera schubarti (Bonetto and Ezcurra de Drago). Rev. Bras. Zool. 19, 123-136.

Batista, T.C.A., Volkmer-Ribeiro, C., Darwich, A., Alves, L.F., 2003. Freshwater sponges as indicators of floodplain lake environments and of river rocky bottoms in Central Amazonia. Amazoniana 17, 525-549.

Batista, T.C.A., Volkmer-Ribeiro, C., Melão, M.G.G., 2007. Espongofauna da Área de Proteção Ambiental Meandros do rio Araguaia (GO, MT, TO), Brasil, com descrição de Heteromeyenia cristalina sp. nov. (Porifera, Demospongiae). Rev. Bras. Zool. 24, 608-630.

Brasil, 2004. Instrução Normativa $n^{\circ} 5$, de 21 de maio de 2004. Reconhece como espécies ameaçadas de extinção e espécies sobreexploradas ou ameaçadas de sobreexploração, os invertebrados aquáticos e peixes, constantes dos Anexos a esta Instrução Normativa. Diário Of. República Fed. do Bras. 1, 136-142. 
Brassac, N.M., Atab, D.R., Landucci, M., Visidoni, N.D., Ludwing, T.V., 1999. Diatomáceas Cêntricas de rios na região de abrangência da usina hidrelétrica de Salto Caxias, PR (Bacia do Rio Iguaçú). Acta Bot. Bras. 13 (3), 277-289.

Campos, J.B., 1999. Spatial and multi-temporal analysis of deforestation and quantification of the remnant forests on Porto Rico Island, Paraná. Braz. Braz. Arch. Biol. Technol. 42, 1190-1999.

Campos, J.B., Costa-Filho, L.V., 1994. Proposta de implantação da área de proteção ambiental do Arquipélago de ilha Grande. SEMA/IAP, Curitiba.

Campos, J.B., Romagnolo, M.B., Souza, M.C., 2000. Structure, composition and spatia distribution of tree species in a remnant of the semideciduous seasonal Alluvia Forest of the upper Paraná River Floodplain. Braz. Arch. Biol.Technol 43, 185-194.

Campos, J.B., Souza, M.C., 1997. Vegetação. In: Vazzoler, A.E.A., Agostinho, A.A. Hahn, N.S. (Eds.), A Planície de Inundação do alto Rio Paraná - Aspectos físicos, biológicos e socioeconômicos. EDUEM, Maringá, pp. 331-342.

Carter, H.J., 1881. History and classification of the known species of Spongilla. Ann. Mag. Nat. Hist 5, 77-107.

Casco, S.I., 2003. Distribución de la vegetación fluvial y su relación con el régimen de pulsos en bajo Paraná. In: Aceñolaza, F.G. (Ed.), Temas de Biodiversidad de Litoral fluvial argentino. San Miguel de Tucumán: Série Miscelánea, vol. 12, pp. $125-131$.

Casco, S.I., Basterra-Chiozzi, N., Neiff, J., 2005. La vegetación como indicador de la Geomorfología Fluvial. Rev. Bras. Geom. 6, 123-136.

Chiarello, E., Amoros, C., Pautou, G., Jolion, J.M., 1998. Succession modeling of river floodplain landscapes. Environ. Model. Softw. 13, 75-95.

Corradini, F.A., Fachini, M.P., Stevaux, J.C., 2008. Geomorfologia e distribuição da vegetação ripária na Ilha Mutum, rio Paraná, PR/MS. Geociências 27, 345-354.

Ezcurra de Drago, I., 1979. Un nuevo genero sudamericano de esponjas: Corvoheteromeyenia gen. nov. (Porifera: Spongillidae). Neotropica 25 (74), 109-118.

Feitosa, Y.O., Absy, M.L., Latrubesse, E.M., Stevaux, J.C., 2015. Late Quaternary vegetation dynamics from central parts of the Madeira River in Brazil. Acta Bot. Bras. 29 (1), 120-128.

Fernandez, O.V.Q., Souza Filho, E.E., 1995. Efeitos do regime hidrológico sobre um conjunto de ilhas no rio Paraná. Bol. Parana. Geociências 43, 161-171.

Frenzel, P., Boomer, I., 2005. The use of ostracods from marginal marine, brackish waters as bioindicators of modern and Quaternary environmental change. Palaeogeogr. Palaeoclimatol. Palaeoecol. 23 (1-4), 68-92.

Gonçalves, A.C., 2014. Estratigrafia e o uso de palinomórfos em estudo da dinâmica sedimentar de formação da ilha Mutum, alto rio Paraná, Brasil. Dissertação Universidade Estadual de Maringá, Maringá, 2014.

IBGE - Instituto Brasileiro de Geografia e Estatística, 2012. Manual Técnico da Vegetação Brasileira, $2^{a}$ ed. Rio de Janeiro.

Kuerten, S., Parolin, M., Assine, M.L., Mcglue, M.M., 2013. Sponge spicules indicate Holocene environmental changes on the Nabileque River floodplain, southern Pantanal. Braz. J. Paleolimnol. 49, 171-183.

Leli, I.T., 2015. Gênese, evolução e morfologia das ilhas e planície de inundação do alto rio Paraná, Brazil. Tese - Universidade Estadual Paulista, Rio Claro, 2015.

Leli, I.T., Stevaux, J.C., Assine, M.L., 2017. Genesis and sedimentary record of blind channel and islands of the anabranching river: an evolution model. Geomorphology 293, 110-130.

McGlue, M.M., Silva, A., Zani, H., Corradini, F.A., Parolin, M., Jabel, E.J., Cohen, A.S , Assine, M.L., Trees, M.A., Kuerten, S., Gradella, F.S., Rasbold, G.G., 2012. Lacustrine records of Holocene flood pulse dynamics in the Upper Paraguay River watershed (Patanal wetlands, Brazil). Quat. Res. 78, 285-294.

Miall, A.D. (Ed.), 1978. Fluvial Sedimentology. Canadian Society of Petroleum Geologists. Memoir 5.

Miall, A.D., 1985. Architectural-element analysis: a new method of facies analysis applied to fluvial deposits. Earth-Sci. Rev. 22 (4), 261-308.

Naiman, R.J., Fetherston, K.L., Mckay, S., Chen, J., 1998. Riparian forests. In: Naiman, R.J., Bilby, R.E. (Eds.), River Ecology and Management: Lessons from the Pacific Coastal Ecoregion. Springer-Verlag, New York, pp. 289-323.

Neiff, J.J., 1986. Las grandes unidades de vegetación y ambiente insular del río Paraná en el tramo Candelaria Itá Ibaté. Rev. Asoc. Cienc. Nat. Litor. St. Tome 17, $7-30$.

Odum, E.P., 1988. Ecologia. Guanabara Koogan, Rio de Janeiro.

Parolin, M., 2006. Paleoambientes e paleoclimas no final do Pleistoceno e no Holoceno no sudeste do Estado do Mato Grosso do Sul. Tese - Universidade Estadual de Maringá, Maringá, 2006.

Parolin, M., Volkmer-Ribeiro, C., Stevaux, J.C.,2003. Caracterização paleoambiental a partir de espículas silicosas de esponjas em sedimentos lagunares na região de
Taquaruçu. In: Dutra, T., Ribeiro, A.M., Kerber, L. (Eds.), Boletim Paleontologia Em Destaque, vol. 44, pp. 17-18.

Parolin, M., Volkmer-Ribeiro, C., Stevaux, J.C., 2007. Sponge spicules in peaty sediments as paleoenvironmental indicators of the Holocene in the upper Paraná river. Braz. Rev. Bras. Paleontol. 10, 17-26.

Parolin, M., Volkmer-Ribeiro, C., Stevaux, J.C., 2008. Use of spongofacies as a proxy for river-lake paleohydrology in Quaternary deposits of Central-Western Brazil. Rev. Bras. Paleontol. 11, 187-198.

Ramírez, A.I.A., 2014. Reconstrucão paleoambiental com base em sementes (semifósseis) na área de protecão ambiental das ilhas e várzeas do rio Paraná, Brasil. Tese - Universidade Estadual de Maringá, Maringá, 2014.

Rasbold, G.G., 2016. Espículas de esponjas de água doce e fitólitos como indicadores das características paleoambientais das Ilhas Bandeirantes e Grande, Alto Rio Paraná desde o Pleistoceno Tardio. Dissertação - Universidade Estadual de Maringá, Maringá, 2016.

Samizava, T.M. Imai, N.N., Rocha, P.C., 2011. Mapeamento das áreas sazonalmente inundáveis do alto curso do Rio Paraná, utilizando dados altimétricos do SRTM e de imagens aéreas. In: Simpósio Brasileiro de Sensoriamento Remoto, 15. (SBSR), 2011. Anais... São José dos Campos: INPE, Curitiba, pp. 4877-4884.

Santos, J.C., Parolin, M., 2011. Distribuição de Esponjas Continentais no rio Mourão. Rev. Geomae 2, 13-22.

Santos, M.L., 2005. Unidades geomorfológicas e depósitos sedimentares associados no sistema fluvial do Rio Paraná no seu curso superior. Rev. Bras. Geom. 6, 85-96.

Santos, M.L., Fernandez, O.V.Q., Stevaux, J.C., 1992. Aspectos morfogenéticos das barras de canal do rio Paraná na região de Porto Rico. PR. Bol. Geogr. 1 (1), $11-24$.

Santos, V.C., Stevaux, J.C., Assine, M.L., 2017. Fluvial processes in attachment bars in the upper Paraná River, Brazil. Geociências 18 (3), 483-499.

Seidl, R., Rammer, W., Spies, T.A., 2014. Disturbance legacies increase the resilience of forest ecosystem structure, composition, and functioning. Ecol. Appl. 24, 2063-2077.

Smith, D.G., 1983. Anastomosed fluvial deposits: modern examples from Western Canada. In: Collinson, J.D., Lewin, J. (Eds.), Modern and Ancient Fluvial Systems. Blackwell Publishing, Oxford, pp. 155-168.

Smith, D.G., 1986. Anastomosed river deposits: sedimentation rates and basin subsidence, magdalena river, north west of colombia, south America. Sediment. Geol. 46, 177-196.

Stevaux, J.C., 1994. The Upper Paraná River (Brazil); geomorphology, sedimentology and paleoclimatology. Quat. Int. 21, 143-161.

Stevaux, J.C., Corradini, F.A., Aquino, S., 2013. Connectivity processes and riparian vegetation of the upper Paraná River, Brazil. J. South Am. Earth Sci. 46, 113-121.

Stevaux, J.C., Parolin, M., Leli, I.T., Stevaux, R., 2009. Alluvial plain constructive processes in the holocene of the Paraná River Brazil. In: Enzel, Y. Greenbaum, N., Laskow, M. (Eds.), GLOCOPH, Israel 2009. The Hebrew University of Jerusalem, Jerusalem, p. 19.

Stevaux, J.C., Souza, I.A., 2004. Floodplain construction in an anastomosed river Quat. Int. 114, 55-65.

Volkmer, C., 1963. Spongilla jewelli n.sp. from Fresh-Water Sponge at Brazil. An. Acad. Bras. Ciênc 35, 271-273.

Volkmer-Ribeiro, C., Ezcurra de Drago, I., Parolin, M., 2007. Spicules of the freshwater sponge Ephydatia facunda indicate lagoonal paleoenvironment at the Pampas of Buenos Aires Province, Argentina. J. Coast. Res. 50, 449-452.

Volkmer-Ribeiro, C., Parolin, M., 2010. As esponjas. In: Parolin, M., VolkmerRibeiro, C., (Org)Leandrini, J.A. (Eds.), Abordagem ambiental interdisciplinar em bacias hidrográficas no Estado do Paraná. Campo Mourão: Editora da Fecilcam, pp. 105-130.

Volkmer-Ribeiro, C., Pauls, S.M., 2000. Esponjas de agua Dulce (Porifera, Demospongiae) de Venezuela. Acta Biol. Venez. 20, 1-28.

Volkmer-Ribeiro, C., Tavares, M.C.M., 1997. Redescrição das esponjas de água doce Oncosclera navicella (Carter, 1881) e Spongilla spoliata Volkmer-Ribeiro e Maciel, 1983 (Spongillidae). Rev. Bras. Biociênc 5, 97-111.

Volkmer-Ribeiro, C., Turcq, B., 1996. SEM analysis of silicious spicules of a freshwater sponge indicate paleoenvironmental changes. Acta Microsc. 5, 186-187.

Ward, J.V., Stanford, A., 1995. Ecological connectivity in alluvial river ecosystems and its disruption by flow regulation. River Res. Appl. 11, 105-119.

Zviejkovski, I.P., 2008. Sucessão em uma pastagem tropical abandonada: mudanças estruturais e estimativa de recuperação florestal. Dissertação - Universidade Estadual de Maringá, Maringá, 2008. 